\title{
Carbon fluxes from subducted carbonates revealed by uranium excess at Mount Vesuvius, Italy
}

Riccardo Avanzinelli, Martina Casalini, Tim Elliott, Sandro Conticelli

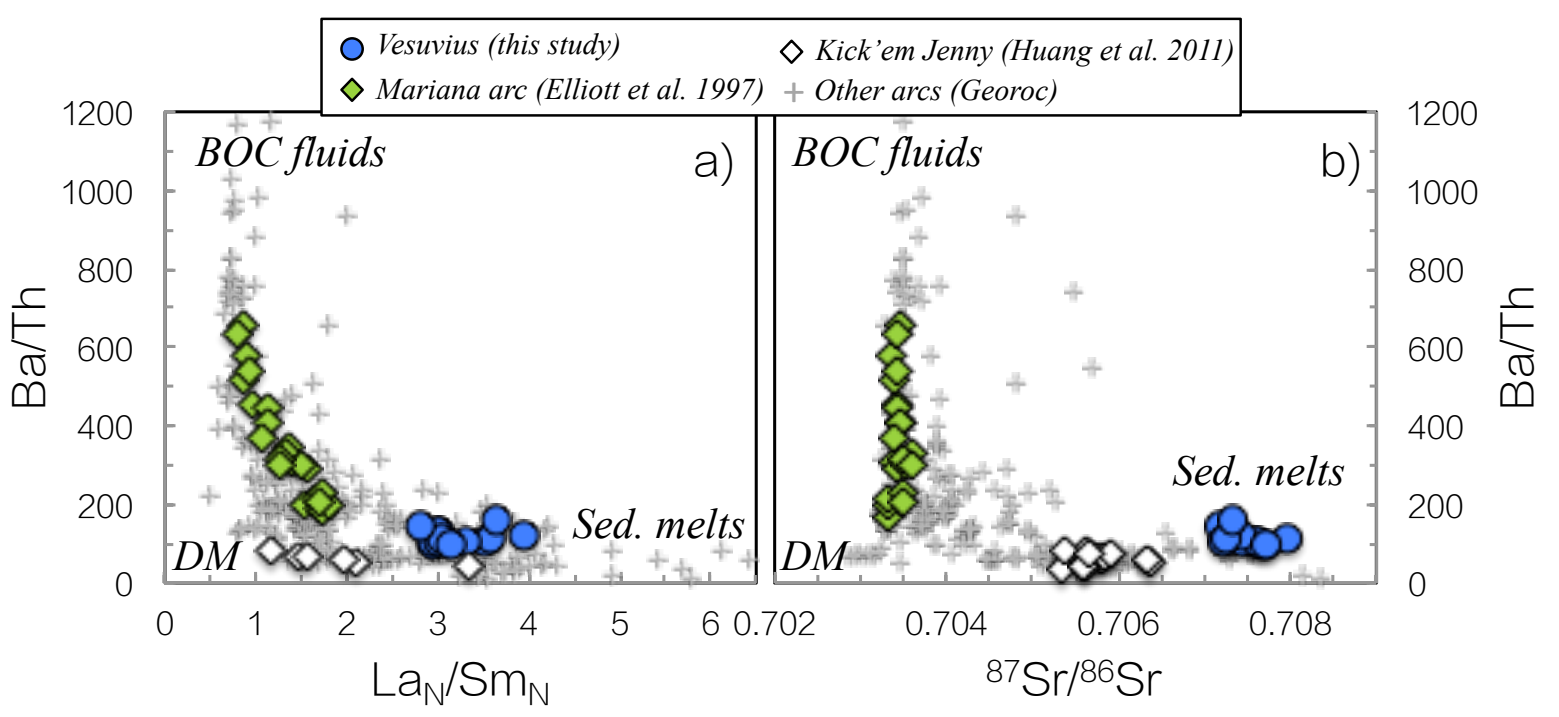

Fig. DR1. Plot of chondrite-normalized $\mathrm{La} / \mathrm{Sm}$ and ${ }^{87} \mathrm{Sr}{ }^{86} \mathrm{Sr}$ vs. Ba/Th. The samples from Vesuvius fall on the 'sediment-dominated' part (i.e. high $\mathrm{La}_{N} / \mathrm{Sm}_{N}$ and ${ }^{87} \mathrm{Sr} /{ }^{86} \mathrm{Sr}$, but low Ba/Th), indicating with a mantle enriched by the addition of melts from subducted sedimentary material.

\section{SAMPLE SELECTION AND ANALYTICAL METHODS.}

Thirteen samples of Vesuvius volcanic rocks (lava flows and scoria), erupted from medieval period (AD 472 - $A D$ 1631) to $A D$ 1944, were selected for this study. In addition few sedimentary carbonate-rich rocks from Apennines were also analyzed and used as a proxy for recycled sediments. Apennines are made up of Tethyan sedimentary sequences scraped off and piled up onto the continental margin during Tethys closure (Treves, 1984). Sample SD 48 and SD 11 are marlstones with variable $\mathrm{CaCO}_{3}$ (SD 48: High-Carbonate, hereafter HC; SD 11: Low Carbonate, hereafter LC) outcropping within the Northern Apennines (Conticelli et al., 2015) whilst sample ERN 57 (Boari et al, 2009a) is a Mesozoic limestone that is representative of the carbonateplatform hosting Vesuvius magma chamber (Del Moro et al., 2001; lacono Marziano et al., 2009).

Samples were powdered and analyzed for major, trace elements and $\mathrm{Sr}-\mathrm{Nd}-\mathrm{Pb}$ isotopes. ${ }^{230} \mathrm{Th}-$ ${ }^{238} \mathrm{U}$ disequilibria were measured in Vesuvius samples; given their age sediments were assumed in secular equilibrium and not measured. A subset of ten samples (including the 3 sediments) was selected for the analysis of ${ }^{238} \mathrm{U} /{ }^{235} \mathrm{U}$.

The whole dataset is provided in tables DR1-4, where further details on the analytical procedures are also reported along with accuracy and reproducibility values based on replicate analyses of international rock standards, as well as further information on the analytical protocols (Avanzinelli et al., 2005, 2014; Hoffman et al., 2007; Andersen et al., 2014; Hiess et al., 2012). 


\section{${ }^{230} \mathrm{Th}^{-238} \mathrm{U}$ DISEQUILIBRIA.}

Uranium series isotopes are short-lived, highly incompatible nuclides that are formed by the decay of long-lived ${ }^{238} \mathrm{U}$ and ${ }^{235} \mathrm{U}$, with ${ }^{230} \mathrm{Th}$ being the short-lived daughter of ${ }^{238} \mathrm{U}$ with a half-life of $\sim 75 \mathrm{kyr}$. The nuclides of each decay chain evolve to a state of "secular equilibrium" with their parents, such that their activities (rates of atomic disintegrations, denoted by round brackets) are equal, which means $\left({ }^{230} \mathrm{Th} /{ }^{238} \mathrm{U}\right)=1$. Disequilibrium can be by fractionation between $U$ and $T h$, yielding $\left({ }^{230} \mathrm{Th} /{ }^{238} \mathrm{U}\right) \neq 1$ with either ${ }^{238} \mathrm{U}$ - or ${ }^{230} \mathrm{Th}$-excess; if the system remains closed, secular equilibrium is then restored in $\sim 5$ half lives of the daughter nuclide $\left(375 \mathrm{kyr}\right.$ for $\left.{ }^{230} \mathrm{Th}\right)$.

For these reasons 'undisturbed' mantle sources (e.g. those within-plate and mid oceanic ridge settings) are considered in secular equilibrium, whilst in subduction-related environment the slabderived components may preferentially introduce $U$ or Th to the mantle wedge, hence producing disequilibria (e.g., Hawkesworth et al., 1993). Despite the similar and highly incompatible character of $U$ and Th in most mineral phases, there are several processes that can produce ${ }^{238} \mathrm{U}_{-}{ }^{230} \mathrm{Th}$ disequilibria, mostly relating to the mechanism of mantle melting and to the geodynamic setting in which magmas are generated (see thorough reviews in Bourdon and Turner, 2003).

MORBs and within-plate magmas generally show ${ }^{230}$ Th excess that are explained with the ingrowth of ${ }^{230} \mathrm{Th}$ during adiabatic mantle melting (e.g., Elliott, 1997). The scenario is more complex in in subduction-related settings, where magmas show variable $\left({ }^{230} \mathrm{Th} /{ }^{238} \mathrm{U}\right)$ that are generally related to the nature of the slab-derived component affecting the mantle wedge (i.e., BOC-fluids vs. sediment melts: Fig. 1; e.g., Elliott, 2003). Large ${ }^{238} \mathrm{U}$-excesses are common in depleted arc lavas and are interpreted as a consequence of aqueous fluid-addition from the altered, mafic oceanic crust (e.g.), due to the higher $U$ in the aqueous fluid phase, with respect to Th. Other authors suggest to that ${ }^{238} \mathrm{U}$ are related to the presence of residual accessory phases, such as allanite (Klimm et al., 2008) preferentially retaining Th during melting of the subducting basaltic oceanic crust (Avanzinelli et al., 2012).

Sediment-dominated, enriched arcs lavas are more variable: a general decrease of ${ }^{238} \mathrm{U}$-excess with increasing Th concentrations in arc lavas (e.g., Condomines and Sigmarrsson, 1993; Hawkesworth et al., 1997) has suggested that sediment melts are added either close to secular equilibrium or that enough time has elapsed since melting that any initial disequilibrium has decayed (Elliott et al., 1997). More recently it has been shown that arc magmas can preserve the ${ }^{230}$ Th-excesses generated during sediment melting (Avanzinelli et al., 2012) due to the preferable retention of $U$ in garnet.

Shallow processes during magma ascent, differentiation and storage in the crust may also affect the U-series composition of the magmas: fractional crystallisation becomes important mostly in the later stages of magma differentiation, due to the highly incompatible behavior of both $U$ and Th in all the major early crystallizing phases (e.g. Blundy \& Wood, 2003); crustal contamination is instead believed to drive the composition of the magmas back towards secular equilibrium (Reubi et al., 2011).

Our model assumes that the ${ }^{238} \mathrm{U}$-excess, as well as $\delta^{238} \mathrm{U}$ and $\mathrm{Sr}-\mathrm{Nd}-\mathrm{Pb}$ isotope ratios measured in the erupted products of Vesuvius are the same of those of their mantle source. This assumption implies that the U-Th disequilibria of Vesuvius lavas ware not modified during mantle melting and magma differentiation and storage. The effects of these processes on the composition of the erupted products and the possible implication for the suggested model are discussed hereafter.

\section{Limestone Assimilation}


Several authors (lacono Marziano et al., 2009; Dallai et al., 2011; Pichavant et al., 2014) have suggested a prominent role for assimilation of limestone affecting both the composition of the erupted magmas and the $\mathrm{CO}_{2}$ emissions. Other studies have provided evidence for an important role of carbonate-rich sediments melts added via subduction to the mantle source of many southern Italian volcanoes (e.g., Peccerillo, 1985; Conticelli and Peccerillo, 1992; Avanzinelli et al., 2008; Frezzotti et al., 2009; Conticelli et al., 2015; Ammannati et al., 2016). The main evidence for this process is the high enrichment in incompatible trace elements of the erupted magmas, both at Vesuvius and in other volcanoes in southern Italy. Such an enrichment cannot be generated by limestone assimilation, which instead should dilute (if any) the incompatible trace element contents in the magmas. A limited trace-element exchange between the host limestone and the magmas was also confirmed by a study on crustal xenoltihs from Vesuvius (Del Moro et al., 2001)

This does not exclude the possibility of the two processes (i.e., limestone assimilation and addition of subduction-related recycling of carbonate-rich sediment melts to the mantle source of the Vesuvius magmas) may coexist (e.g., Boari et al., 2009b). For the purpose of this study it is important to evaluate to what extent the assimilation of wall-rock limestone have affected the $U$ elemental and isotopic composition Vesuvius magmas, and thus whether or not it can be responsible for the ${ }^{238} U$-excess that are used here as evidence of the deeper addition of carbonate-rich sediment melts to the mantle wedge.

In order to evaluate the effect of such a process on both $\left({ }^{230} \mathrm{Th} /{ }^{238} \mathrm{U}\right)$ and ${ }^{238} \mathrm{U} /{ }^{235} \mathrm{U}$ of Vesuvius magmas we measured $\delta^{238} U$ of one sample of Mesozoic limestone (ERN 57) belonging to the carbonate platform that constitute the country rocks hosting the Vesuvius magma chamber. This sample shows an extremely light $U$ isotope composition $\left(\delta^{238} U=-0.67 \%\right.$ ) opposite to the shift from mantle towards higher $\delta^{238} \mathrm{U}$ shown by Vesuvius samples.

Limestone hosts significantly more $U$ than Th, resulting in high $U / T h$ and developing over time extremely high $\left({ }^{230} \mathrm{Th} /{ }^{232} \mathrm{Th}\right.$ ) (Fig. DR 3). As an example, assuming secular equilibrium, sample ERN 57 has $\left({ }^{238} \mathrm{U} /{ }^{232} \mathrm{Th}\right)=\left({ }^{230} \mathrm{Th} /{ }^{232} \mathrm{Th}\right)=6.85$; the same holds true considering a limestone sample erupted as xenolith within the 1944 eruption of Vesuvius (sample C-5 and C-3 from Del Moro et al., 2001) having $\left({ }^{238} \mathrm{U} /{ }^{232} \mathrm{Th}\right)=\left({ }^{230} \mathrm{Th} /{ }^{232} \mathrm{Th}\right)>14$.

Vesuvius samples have both $\left({ }^{238} \mathrm{U} /{ }^{232} \mathrm{Th}\right)$ and $\left({ }^{230} \mathrm{Th} /{ }^{232} \mathrm{Th}\right)$ significantly lower than limestone, with $\left({ }^{238} \mathrm{U} /{ }^{232} \mathrm{Th}\right)$ ranging from 0.91 to 1.21 and a smaller variation in $\left({ }^{230} \mathrm{Th} /{ }^{232} \mathrm{Th}\right)$, from 0.96 to 1.07 , resulting in variable ${ }^{238} \mathrm{U}$-excesses that define a quasi-horizontal trend in the classic equiline diagram (Fig. DR2). It is difficult to asses whether assimilation would involve partial or total melting of the host limestone, and, in the first case, whether wall-rock partial melting would produce fractionation between $U$ and Th (hence producing $U$ or Th excesses); in either case, the assimilated material would invariably have extremely high $\left({ }^{230} \mathrm{Th} /{ }^{232} \mathrm{Th}\right)$, hence producing a significant effect on the $\left({ }^{230} \mathrm{Th} /{ }^{232} \mathrm{Th}\right)$ of the contaminated magmas. In the figure the bulk assimilation of such high $\left({ }^{238} \mathrm{U} /{ }^{232} \mathrm{Th}\right)$ and $\left({ }^{230} \mathrm{Th} /{ }^{232} \mathrm{Th}\right)$ is modeled starting from both the sample with both the smallest and largest ${ }^{238} \mathrm{U}$-excess, in order to evaluate whether such a process could be responsible for the isotope variation observed at Vesuvius. Figure DR2 clearly shows that the assimilation of limestone, even at the higher extent suggested for Vesuvius (up to of $10-15 \%$ : lacono Marziano et al. 2009), could produce some of the scattering shown by the dataset, but it cannot be responsible for the horizontal displacement of the samples toward high $\left({ }^{238} \mathrm{U} /{ }^{232} \mathrm{Th}\right)$ and thus toward the observed ${ }^{238} \mathrm{U}$-excess. 


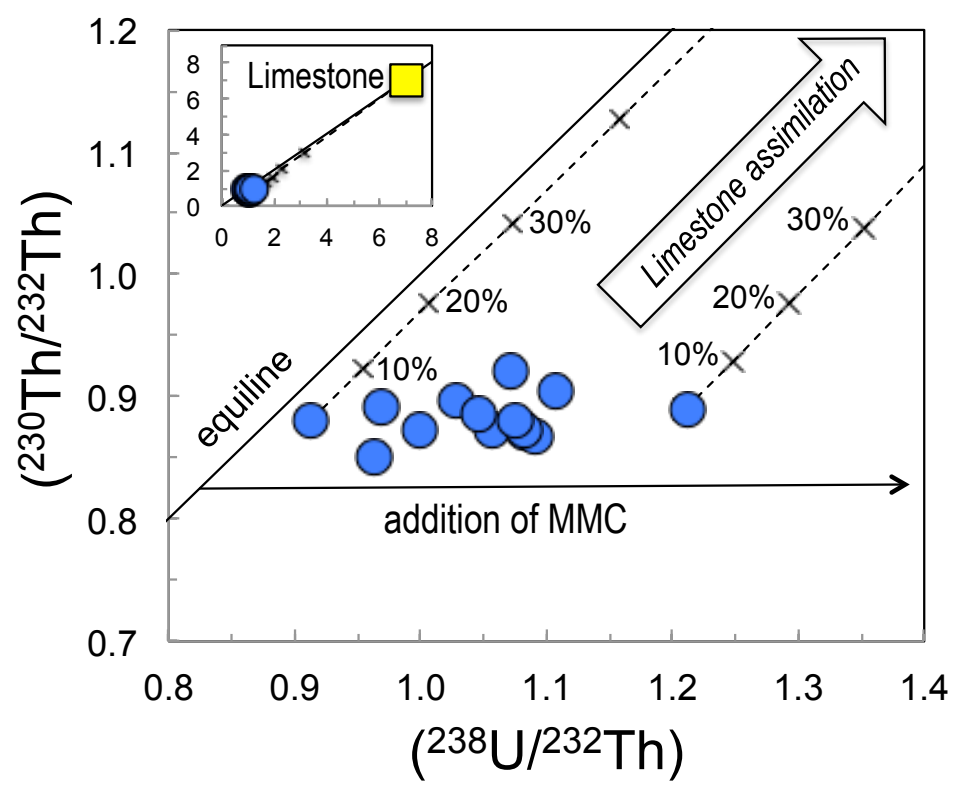

Fig. DR2. Effect of wall-rock limestone assimilation on the U-series activity ratios of Vesuvius volcanic rocks. Dotted lines represent bulk mixing of Mesozoic limestone ERN 57 with the two magmas with the highest and lowest ${ }^{238} \mathrm{U}$-excess. The isotope composition of the wall rock limestone (shown in the inset) is calculated from its $U$ and Th content (Table DR1) assuming secular equilibrium. For comparison un-metamorphosed limestone xenoliths erupted within 1944 (Dal Moro et al., 2001) yield recalculated $\left({ }^{238} \mathrm{U}^{232} \mathrm{Th}\right)=$ $\left.{ }^{230} \mathrm{Th}^{232} \mathrm{Th}\right)$ varying from 15 to 105 . Error bars are smaller than the symbols.

\section{Fractional crystallization and mantle melting}

As stated above, fractional crystallization has also little effect on both $U$ and Th due to their similar and high incompatibility in the main crystallizing phases, unless significant amounts of $U$ - or Thrich phases (e.g., apatite) are fractionated. At Vesuvius no correlation is observed between ${ }^{238} U$ excess and any fractionation index (e.g., $\mathrm{MgO}$ ) including those sensitive to apatite fractionation (i.e., $\mathrm{P}_{2} \mathrm{O}_{5}$ ).

Mantle melting may affect $\left({ }^{230} \mathrm{Th} /{ }^{238} \mathrm{U}\right)$ according to time-dependent melting models (e.g., Elliott, 1997) that have been applied to subduction-related magmatism (e.g., Thomas et al., 2002; Avanzinelli et al., 2012). The net effect of melting on ${ }^{230} \mathrm{Th}^{238} \mathrm{U}$ is to decrease the extent ${ }^{238} \mathrm{U}$ excess in the erupted magmas with respect to the original value of their mantle source, due to the time-dependent ingrowth of ${ }^{230}$ Th during melting (Avanzinelli et al., 2012; Elliott, 1997; Thomas et al., 2002; Zou and Zindler, 2000). A detailed quantification of this process is beyond the purpose of this study and will require additional data on other U-series parent-daughter disequilibria (such as ${ }^{231} \mathrm{~Pa}^{235} \mathrm{U}$ ). Accounting for the possible effect of mantle melting would require to infer a slightly greater initial ${ }^{238} \mathrm{U}$-excess in the mantle source; this would consequently require a larger addition of U-rich MMC, eventually resulting in slightly larger estimates of $\mathrm{CO}_{2}$ fluxes than those estimated (Fig. 3). On the other hand, the 'ingrowth' effect on ${ }^{230} \mathrm{Th}^{238} \mathrm{U}$ disequilibria of arc magmas is generally small with respect to other parent daughter pairs (Avanzinelli et al., 2012), as confirmed by the near equilibrium composition of many arcs (Condomines and Sigmarsson, 1993). Considering this, $\mathrm{CO}_{2}$ fluxes calculated by our model (see details below) might be slightly underestimated, although we believed that the potential effect of such a process should be smaller than the uncertainty of some used parameters, which is accounted for in our Monte Carlo simulation (Fig. 3., details in the calculations are provided below).

\section{MODELLING THE MANTLE SOURCE OF VESUVIUS MAGMAS.}

Vesuvius magmas are invariably characterized by radiogenic $\mathrm{Sr}$ and $\mathrm{Pb}$ and unradiogenic $\mathrm{Nd}$ isotope composition, indicating a crustal component within their mantle source, regardless of the extent of the U-series disequilibria (Figs. 1, DR1). Therefore, we adopted a two-step enrichment model: i) a first enrichment capable of producing the composition of the lavas with no ${ }^{238} \mathrm{U}$-excess; ii) a second step accounting for the addition of the Marl Melt Component (i.e., MMC) and thus the ${ }^{238} \mathrm{U}$-excess. 
For this first step we applied mixing models using the end-members compositions of mantle wedge (i.e., MW) and slab-derived component (i.e., SC) reported for the neighboring Stromboli volcano (Tommasini et al., 2007) (Table DR5). Stromboli and Vesuvius volcanic products show several similarities in terms of geochemical and isotopic composition (Fig. DR3) suggesting a common (or similar) mantle source (Peccerillo, 2001). The lack of ${ }^{238} \mathrm{U}$-excess at Stromboli (Tommasini et al., 2007) indicates, however, that Stromboli magmas must originate from a mantle source not affected by the contribution of the U-rich MMC.

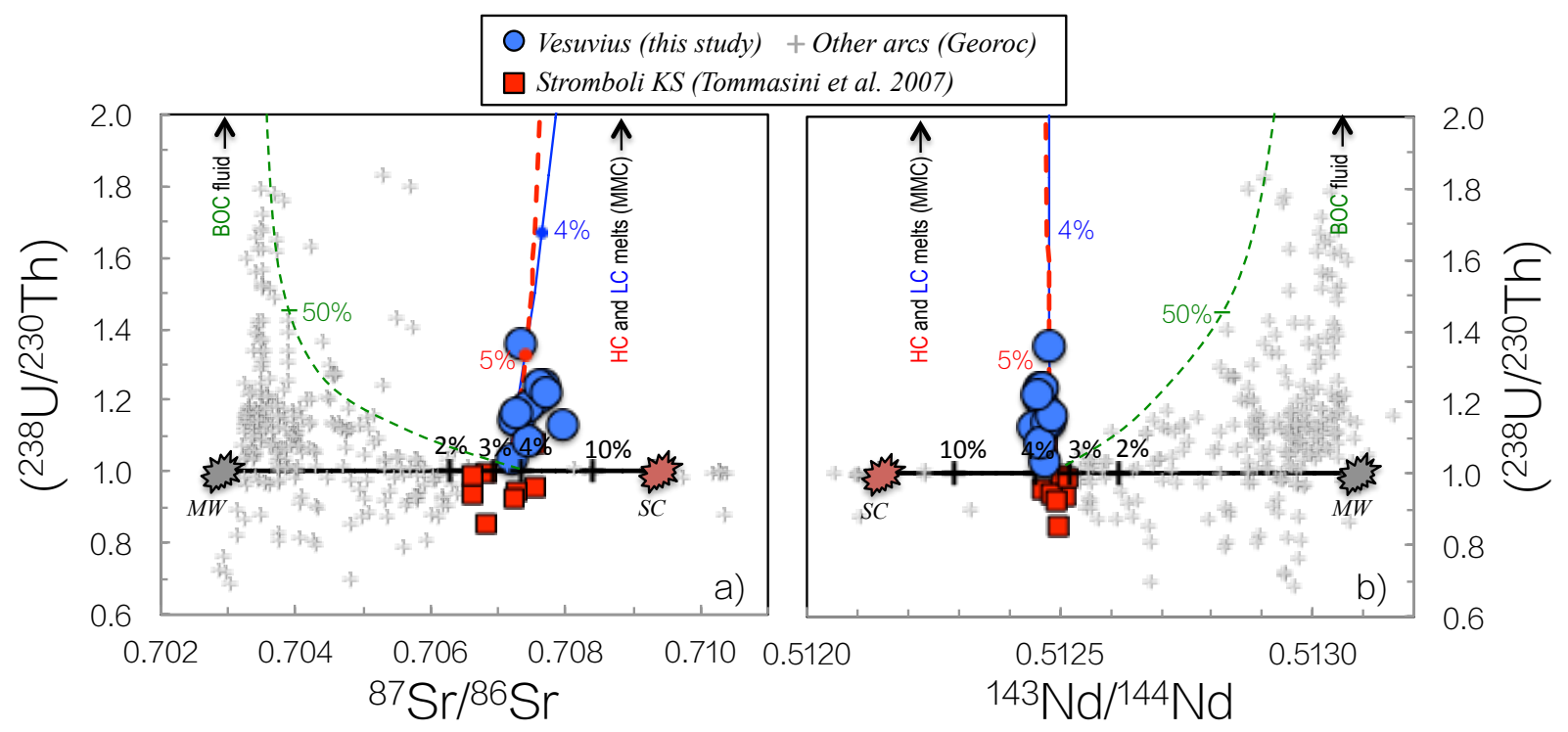

Fig. DR3. Two-step mixing between process. The green, red and blue mixing curves are calculated between a mantle source enriched with $3.5 \%$ of SC (step I - Table DR5) and the BOC fluid, the HC and the LC melt, respectively (Step II: Table DR5). HC and LC melts represent two possible compositions of the U-rich MarlMelt Component (MMC) starting from sediment samples SD 48 (High-Carbonate marl, HC) and SD 11 (LowCarbonate marl, LC). Samples from Stromboli are reported as red squares.

Both MW and SC (Table DR5) were assumed having secular equilibrium $\left({ }^{230} \mathrm{Th} /{ }^{238} \mathrm{U}\right.$ ) and $\delta^{238} \mathrm{U}$ equal to the bulk-earth average (i.e., $-0.33 \%$ : Andersen et al., 2015). From this calculation we estimated a mantle enriched by an average of $3.5 \%$ SC as a starting point to model the second step (Fig. DR3, Table DR5).

In the second step we modeled the addition of the MMC into the previously enriched (Step I) mantle. The geochemical and isotopic composition of the two possible U-rich MMCs shown in figure 2 (and Fig. DR3) were calculated starting from the two marl sediments measured in this study (Tables DR1-4) and modeling sediment melting according to the experiments of Skora et al. (2015) (Table DR5). For each sediment sample we used the melting parameters reported for similar lithologies (HC for SD 48 and LC for SD 11). We chose run conditions characterized by the presence of residual epidote (in order to produce the enrichment in $U$ over $T h$ in the resulting melts) and by the complete exhaustion of phengite (which would have retained $\mathrm{K}$ and $\mathrm{Rb}$, resulting in a depletion of such elements not observed in the data). The temperatures of the experimental runs $\left(850-900^{\circ} \mathrm{C}\right)$ are slightly higher than those estimated at the slab/mantle interface by thermal models of both 'cold' subduction (e.g., Peacock, 2003: Kelemen et al., 2003). This can be explained, for example assuming the physical incorporation of portions of the subducted sediments into the mantle, by imbrication, as melanges or via diapirs (e.g., Kelemen et al., 2003: Gerya et al., 2006, Nielsen and Marshall, 2017), and their melting at higher temperatures (Fig. DR4). 


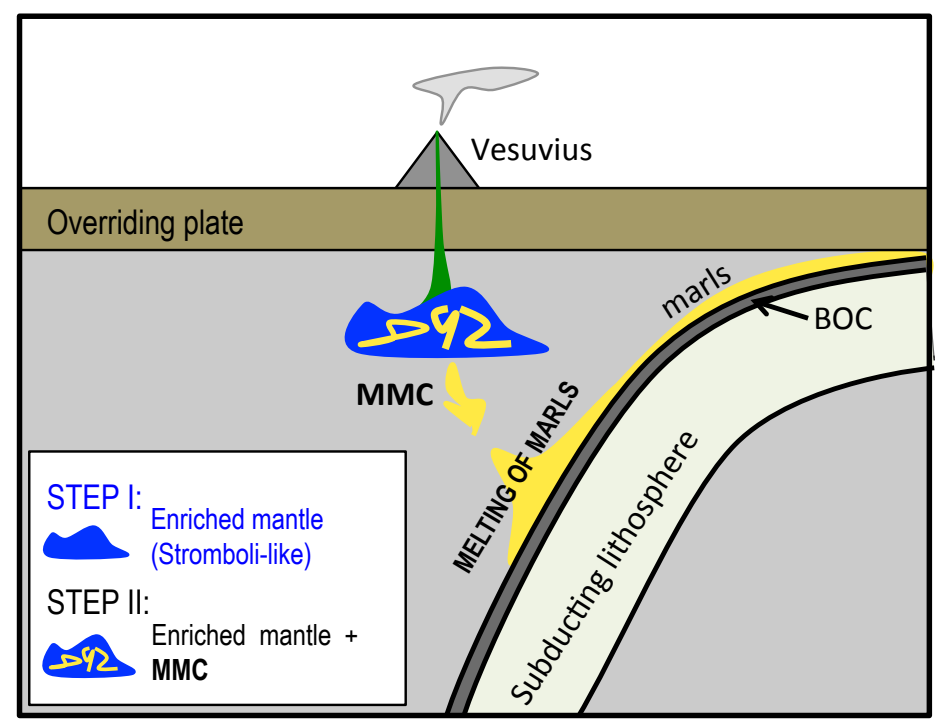

Fig. DR4. Simplified illustration of the two-step enrichment process operating under Vesuvius. Melting of subducted marls (with residual epidote) generates the MMC that reacts (Step II) with a previously enriched (Step I) mantle, hence imparting the observed ${ }^{238} U$-excess to the mantle source of Vesuvius. The MMCenriched mantle source then undergoes melting to generates Vesuvius magmas

The composition of the BOC fluid used in figures 2 and DR3 (from Avanzinelli et al. 2012, Andersen et al., 2015) is also reported in Table DR5. It is worth stressing that the correlation between U-Th disequilibria and both $\delta^{238} \mathrm{U}$ and $\mathrm{Sr}-\mathrm{Nd}-\mathrm{Pb}$ isotopes is not as good as it would be expected for a simple two end-members mixing model. This suggests that the marl melt component (MMC) is not isotopically homogeneous, hence it may derive from several isotopically different starting sediments undergoing subduction and melting. Moreover, the U/Th of the sediment melt is dictated by the phase relations during melting, and it is not inherited from the original down-going sediment.

Most of the data in figure 2 and DR3 can be reproduced by the addition of the two proposed MMC components. Other samples show higher $\delta^{238} \mathrm{U}$ and ${ }^{87} \mathrm{Sr} /{ }^{86} \mathrm{Sr}$, suggesting the involvement of a component with slightly different isotope composition. Regardless of this complexity, our data clearly shows that the ${ }^{238} \mathrm{U}$-excess observed at Vesuvius can be obtained only through the addition of sediment-melt component, and cannot be due to addition of BOC fluid-like agents as it occurs in more typical island arc settings (e.g., Marianas).

The mixing models performed in this study are therefore used to provide an estimate, as good as possible, of the amount of MMC recycled into the mantle source of Vesuvius, especially for constraining the $U$ mass balance that will be used in the next section in the attempt of quantifying $\mathrm{CO}_{2}$ fluxes. The key parameters in this calculation are the $U$ content and U/Th of the modeled MMC, whilst its $\mathrm{Sr}-\mathrm{Nd}-\mathrm{Pb}$ isotope composition and $\delta^{238} \mathrm{U}$, has no effect on the results.

The experimental study of Skora et al. (2015) shows that melts produced by carbonate-rich sediments in the presence of residual epidote have higher $\mathrm{Ba} / \mathrm{Th}$ than those produced by carbonate-poor epidote-free lithologies. Ba/Th of Vesuvius is lower with respect to 'fluid-dominated' arcs (Fig. DR1), but it is higher than that of other Italian potassic rocks (Avanzinelli et al., 2008) and Stromboli. In fact, the slight increase of $\mathrm{Ba} / \mathrm{Th}$ from the values observed in the potassic rocks of Stromboli (i.e., Ba/Th = 80-95: Tommasini et al., 2007) - which are considered here as representative of the first step of subduction-related mantle enrichment - to the higher values of Vesuvius rocks (i.e., Ba/Th $=92-140$, Table DR1) is consistent with the further addition of the $\mathrm{MMC}$, in the two-step process suggested in this study. These melts, would then react with the previously metasomatised mantle wedge along the lines of the process described in detail in Ammannati et al (2016). 


\section{ESTIMATING MMC-DERIVED $\mathrm{CO}_{2}$ FLUXES.}

Since the U-rich MMC is released by recycled sedimentary carbonates, we attempted to constrain how much of its $\mathrm{CO}_{2}$ was released during subduction and thus the flux of $\mathrm{MMC}$-derived $\mathrm{CO}_{2}$ affecting the mantle source of the magmas. This is an extremely complex task, due to the large number of variables that affect the calculation and are difficult to constrain.

MMC derived $\mathrm{CO}_{2}$ fluxes ( $f_{\text {CO2-MMC }}$ ) was calculated as follows:

$f_{C O 2-M M C}=f_{M M C} \times\left[\mathrm{CO}_{2}\right]_{M M C}$

where $\left[\mathrm{CO}_{2}\right]_{M M C}$ is the amount of $\mathrm{CO}_{2}$ carried with the MMC (in wt\%) and $f_{M M C}$ is the mass flux $(\mathrm{Mt} / \mathrm{yr})$ of $\mathrm{MMC}$ into the mantle source of Vesuvius over the investigated period, that is:

$f_{M M C}=f_{M S} \times \% M M C$

where \%MMC is the proportion (as wt\%) of MMC required to produce the observed U-excess, extrapolated from the two-step mixing model and $f_{M S}$ is the mass flux of mantle source undergoing melting, and thus producing magmas. The latter (i.e., $f_{M S}$ ) was calculated by mass balancing $U$ as

$f_{M S}=\frac{f U_{M S}}{[U]_{M S}}$

where $[U]_{M S}$ is the average concentration of $U$ in the mantle source calculated through the two-step enrichment model described above, and $f U_{M S}$ is, that is the total mass of $U$ involved in the melting process (partitioned between the melt and the residue) divided by the considered period of activity (A.D. 1697 - 1944), that is the mass flux of $U$ from the mantle source.

Considering the extreme incompatibility of $U$ both during mantle melting and magma differentiation (Blundy and Wood, 2003), it can be assumed that all the $U$ has been completely partitioned in the magmas and then in the erupted products (i.e., negligible $U$ is lost in the residual mantle or fractionated by crystallized mineral phases). This means that all the $U$ hosted in the mantle source is directly transferred to the erupted magmas, hence $f U_{M S}$ is equal to the mass flux $U$ erupted $\left(f U_{E R}\right)$, which in turn can be calculated as:

$f U_{M S}=f U_{E R}=[U]_{E R} \times O R_{1697-1944}$

where $\left[U_{E R}\right]$ is the average concentration of $U$ in the erupted products and $O R_{1697-1944}$ is the output rate in Mt/yr estimated for Vesuvius during the 1697-1944 period (Cortini and Scandone, 1982; Scandone et al., 1986; Santacroce et al., 1993; Scandone et al., 2008: generally published values are available as volume/year).

Merging these four simple relations, the $\mathrm{MMC}$-derived $\mathrm{CO}_{2}$ fluxes can be expressed as:

$f_{C O 2-M M C}=\left\{\left[\frac{\left([U]_{E R} \times O R_{1697-1944}\right)}{[U]_{M S}}\right] \times \% M M C\right\} \times\left[C O_{2}\right]_{M M C}$

The parameters involved in the calculation are extremely difficult to constrain and even the best estimate of them may carry large uncertainty. In order to account for this large variability we performed Monte Carlo simulation letting all the parameters varying between a maximum and a minimum value.

The results of our Monte Carlo simulation are shown in figure 3 and yields $f_{\text {CO2-Mmc }}$ between 0.2 and $0.8 \mathrm{Mt} / \mathrm{yr}$. The ranges used for each parameter are reported in Table DR7, and are discussed in more details hereafter.

\section{$\mathrm{CO}_{2}$ contents of the MCC: [CO2] $]_{M M C}$.}

The study of Skora et al. (2015) reports the $\mathrm{CO}_{2}$ content of the starting sedimentary materials, but unfortunately does not provide its concentration (or estimates of it) in the sediment melts, also due 
to the occurrence of fish eggs testifying the presence of a coexisting fluid phase which was not measured. The paper however, provides the final phase proportion, for each experiment, including the amount of residual carbonate and melt generated.

Starting from the initial $\mathrm{CO}_{2}$ contents and the phase proportions, we calculated the amount of $\mathrm{CO}_{2}$ lost during the experiments, by assuming that all the $\mathrm{CO}_{2}$ retained in the residue was hosted within the carbonate phase. The amount of retained $\mathrm{CO}_{2}$ was then calculated by simply allotting it into the carbonate using stoichiometric estimation. The remaining amount of $\mathrm{CO}_{2}$ (i.e., the portion lost during the melting experiment) was then redistributed into the fraction of melt produced during the experiment, so to calculate a wt \% value. This is obviously a simplification, since it does not account for the mass of the coexisting liquid phase, which means implicitly assuming to be negligible with respect to that of the melt.

The application of this approach for the starting sediments of Skora et al. (2015) yields $\sim 8$ and $\sim 9$ wt\% of $\mathrm{CO}_{2}$ released during the partial melts of the Low-Carbonate (LC) and High-carbonate (HC) lithologies, respectively (Table DR6). The somewhat surprisingly similar values are explained by the smaller amount of residual carbonate in the experiment involving the carbonate-poor lithology, so that almost all of its $\mathrm{CO}_{2}$ is released during the melting experiment, whilst during the experiments performed with the carbonate-rich lithology a significant part of $\mathrm{CO}_{2}$ is retained in the residue.

The two Italian marlstones, SD 48 and SD 11 used in our calculation are very similar in bulk composition to the carbonate-rich ( $\mathrm{HC}$ ) and carbonate-poor (LC) lithology used by Skora et al. (2015), respectively. Initial $\mathrm{CO}_{2}$ contents of SD 48 and SD 11 are not available and it is also difficult to assess their phase proportion during melting; assuming the same $\mathrm{CO}_{2} / \mathrm{LOI}$ ratio and phase proportion of the respective HC and LC of Skora et al. (2015), the amount of $\mathrm{CO}_{2}$ carried with the sediment melt would be $\sim 12 \mathrm{wt} \%$ for SD 48 and $\sim 9 \mathrm{wt} \%$ for SD 11 (Table DR6).

Whether the suggested amount of $\mathrm{CO}_{2}$ is dissolved in the melts or carried as a separate fluid or gas phase is difficult to constrain, since it is related to the solubility of $\mathrm{CO}_{2}$ in the melt which depends in turn on several parameters (e.g., pressure, amount of dissolved water, $f_{\mathrm{CO} 2}$, and melt composition, e.g., Ni and Keppler, 2013). Considering that the total mass of such fluid or gas phase should be negligible with respect to that of the sediment melt, aforementioned values were assumed as the wt\% amount of $\mathrm{CO}_{2}$ carried along with the U-rich MMC, regardless of the physical form in which it is transferred.

According to the considerations made above we used a possible range of $\mathrm{CO}_{2}$ contents for the MMC between 8 and 13 wt.\%.

$\% M M C,[U]_{E R,}$ and $[U]_{M S}$.

For any $U$ isotope composition, the enrichment model allows to calculate the amount of MMC required (\%MMC) and the resulting $U$ content in the mantle source $\left([U]_{M S}\right)$. Excluding three medieval samples (AD 472 - AD 1631), for which is more difficult to find estimates of output rates (see hereafter), our dataset includes volcanic products from AD 1697 to AD 1944, with U concentrations $\left([U]_{E R}\right)$ ranging from 5.7 and $7.5 \mathrm{ppm}$ (i.e., similar to the overall variation reported on Georoc for the same periods of activity).

These samples have mean $\left({ }^{230} \mathrm{Th} /{ }^{238} \mathrm{U}\right) \sim 0.86$ that are best reproduced with the addition of $\sim 2.5$ of the $\mathrm{HC}$ or $\sim 1.0 \%$ of the LC sediment melt, respectively (Table DR5). In the two-step melting model adopted, the aforementioned additions of MMC produce a metasomatised mantle source with almost identical $U$ content, $\sim 0.28$ to $0.29 \mathrm{ppm}$ (Table DR5), due to the higher initial concentration in the LC starting sediment (SD 11). 


\section{Output rates: $\mathrm{OR}_{1697-1944}$}

Santacroce et al. (1993) calculated output fluxes of 3.5-4-0 × $10^{6} \mathrm{~m}^{3} / \mathrm{yr}$ for the AD 1872 - AD 1906 activity and similar values (i.e., $3.9 \times 10^{6} \mathrm{~m}^{3} / \mathrm{yr}$ ) were suggested by Scandone et al. (1986) from AD 1906 to AD 1944., A more recent study (Scandone et al., 2008) investigated in detail the volcanic activity of Vesuvius from AD 1638 and AD 1944, providing estimates of the supply rates of several eruptions as well as the duration of the refilling process. From those estimates it is possible to calculating the total mass of magma supplied to the system and to redistribute it through the 306 year-span, resulting in a mean supply rate of $3.0 \times 10^{6} \mathrm{~m}^{3} / \mathrm{yr}$, similar to the previous estimates.

According to these estimates the MMC-derived $\mathrm{CO}_{2}$ fluxes were calculated with output rates ranging between $3.0 \times 10^{6} \mathrm{~m}^{3} / \mathrm{yr}$ and $4.0 \times 10^{6} \mathrm{~m}^{3} / \mathrm{yr}$, yielding a total range of possible values between $\sim 0.2 \mathrm{Mt} / \mathrm{yr}$ and $\sim 0.8$ (Fig. 3).

It is important to stress that, however, in the study of Scandone et al. (2008) the time accounted by the supplying periods adds up to cover only 140 of the total 306 year-span. This indicate that magma arrival in the system is not a continuous process, but it occurs in phases of high, yet variable, supply rate alternated with periods with no magma supplied to the system. Accordingly it was suggested a mean supply rate for the 'active' periods of $\sim 5.7 \times 10^{6} \mathrm{~m}^{3} / \mathrm{yr}$ (Scandone et al., 2008), which is significantly higher than the values reported above. In terms of $\mathrm{CO}_{2}$ fluxes, this would convert in 'active' periods with average MMC-derived fluxes between 0.7 and $1.2 \mathrm{Mt} / \mathrm{yr}$ (depending on the $\mathrm{CO}_{2}$ content of $\mathrm{MCC}$ ) alternated by periods with negligible $\mathrm{MCC}$ derived $\mathrm{CO}_{2}$.

Comparison with directly measured $\mathrm{CO}_{2}$ fluxes.

The present day emissions of $\mathrm{CO}_{2}$ at Vesuvius, $0.1 \mathrm{Mt} / \mathrm{yr}$ (i.e., 300t/day: Caliro et al., 2005, Frondini et al., 2004, lacono Marziano et al., 2009) estimated from the isotopic composition of groundwater (Caliro et al., 2005) and diffused soil degassing (Frondini et al., 2004), are lower than those indicated by our calculation.

This is not surprising if considering what discussed in the previous section. At present Vesuvius shows no sign of significant input of magma in the systems, and also the release of magmatic $\mathrm{CO}_{2}$ may be limited by the lack of an open conduit system, which might instead being present during the AD 1631 - AD 1944 period (Scandone et al., 2008). On the other hand it must be taken into account that a significant portion of the present day-emission at Vesuvius might be due to the interaction between the magma and the limestone in the shallow crust (lacono Marziano et al., 2009; Dallai et al., 2011; Pichavant et al., 2014). In addition, it must be considered that much larger fluxes are suggested for the whole Campanian area ( $3 \mathrm{Mt} / \mathrm{yr}$ Chiodini et al., 2004). Considering the presence in the Campanian area of other volcanoes, such as Ischia and the Phlegrean Fields, that have erupted significant volumes of products showing 'sediment-dominated' isotope compositions with ${ }^{238} \mathrm{U}$-excess (Avanzinelli et al., 2008), we suggest that the $\mathrm{MMC}$-derived $\mathrm{CO}_{2}$ fluxes may represent a significant, portion of the total $\mathrm{CO}_{2}$ budget of the area.

An interesting datum against which to compare our estimates of $\mathrm{MMC}$-derived $\mathrm{CO}_{2}$ fluxes is the present-day mean plume $\mathrm{CO}_{2}$ flux measured at Stromboli (i.e., $0.73 \mathrm{Mt} / \mathrm{yr}$ : Burton et al., 2013). Stromboli is a presently active, open-conduit volcano, characterized by a style of activity and output fluxes (Marsella et al., 2012) comparable to that of Vesuvius from AD 1631 to AD 1944 (Scandone et al., 2008) and with no evidence of shallow interaction with carbonates. Also, the mantle source of Stromboli is similar to that of Vesuvius, except for the lack of the U-rich MMC. Assuming that the $\mathrm{CO}_{2}$ flux measured at Stromboli may represent a proxy for the first step of mantle enrichment also at Vesuvius, we can argue that the MMC-derived fluxes at Vesuvius may account for a significant portion (up to half according to our calculation) of its deep (i.e., mantle derived) $\mathrm{CO}_{2}$. 


\section{ADDITIONAL REFERENCES}

Andersen, M.B., Romaniello, S., Vance, D., Little, S.H., Herdman, R., and Lyons, T.W.A, 2014, Modern framework for the interpretation of ${ }^{238} \mathrm{U} /{ }^{235} \mathrm{U}$ in studies of ancient ocean redox: Earth and Planetary Science Letters, v. 400, p. 184-194.

Avanzinelli, R., Boari, E., Conticelli, S., Francalanci, L., Guarnieri, L., Perini, G., Petrone, C. M., Tommasini, S., and Ulivi, M., 2005, High precision $\mathrm{Sr}$, $\mathrm{Nd}$, and $\mathrm{Pb}$ isotopic analyses using new generation thermal ionisation mass spectrometer: aims and perspective for isotope geology applications: Periodico di Mineralogia, v. 74, p. 147-166.

Avanzinelli, R., Braschi, E., Marchionni, S., and Bindi, L., 2014, Mantle melting in within-plate continental settings: $\mathrm{Sr}-\mathrm{Nd}-\mathrm{Pb}$ and $\mathrm{U}$-series isotope constraints in alkali basalts from the Sicily Channel (Pantelleria and Linosa Islands, Southern Italy): Lithos, v. 188, p. 113-129.

Baker, J., Peate, D., Waight, T., and Meyzen, C., 2004, Pb isotopic analysis of standards and samples using a ${ }^{207} \mathrm{~Pb}-{ }^{204} \mathrm{~Pb}$ double spike and thallium to correct for mass bias with a doublefocusing MC-ICP-MS: Chemical Geology, v. 211, p. 275-303.

Boari, E., Tommasini, S., Laurenzi, M.A., and Conticelli, S., 2009a, Transition from ultrapotassic kamafugitic to sub-alkaline magmas: $\mathrm{Sr}, \mathrm{Nd}$, and $\mathrm{Pb}$ isotope, trace element and ${ }^{40} \mathrm{Ar}-{ }^{39} \mathrm{Ar}$ age data from the Middle Latin Valley volcanic field, Roman Magmatic Province, Central Italy: Journal of Petrology, v. 50, p. 1327-1357.

Boari, E., Avanzinelli, R., Melluso, L., Giordano, G., Mattei, M., De Benedetti, A., Morra, V., and Conticelli, S., 2009b, Isotope geochemistry ( $\mathrm{Sr}-\mathrm{Nd}-\mathrm{Pb})$ of leucite-bearing volcanic rocks from 'Colli Albani' volcano, Roman Magmatic Province, Central Italy: inferences on volcano evolution and magma genesis: Bulletin of Volcanology v. 71, p. 977-1005.

Bourdon, B., Henderson, G.M., Lundstrom, C.C., and Turner, S.P., eds., 2003. Uranium-Series Geochemistry: Reviews in Mineralogy and Geochemistry v. 52, 656pp.

Conticelli, S., and Peccerillo, A., 1992. Petrology and geochemistry of potassic and ultrapotassic volcanism in central Italy: petrogenesis and inferences on the evolution of the mantle sources: Lithos v. 28, p. 221-240.

Cortini, M., and Scandone, R., 1982, The feeding system of Vesuvius between 1754 and 1944: Journal of Volcanology and Geothermal Research, v. 12, p. 393-400.

Dallai, L., Cioni, R., Boschi, C., and D'Oriano, C., 2011, Carbonate derived $\mathrm{CO}_{2}$ purging magma at depth: influence on the eruptive activity of Somma-Vesuvius, Italy: Earth and Planetary Science Letters, v. 310, p. 84-95.

Del Moro, A., Fulignati, P., Marianelli, P., and Sbrana, A., 2001, Magma contamination by direct wall-rock interaction: constraints from xenoliths from the walls of a carbonate-hosted magma chamber (Vesuvius 1944 eruption): Journal of Volcanology and Geothermal Research, v. 112, p. 15-24.

Elliott, T., 1997, Fractionation of $U$ and Th during mantle melting: a reprise: Chemical Geology, v. 139, p. 165-183.

Gerya, T.V., Connolly, J.A.D., Yuen, D.A., Gorczyk, W., and Capel, A.M. 2006, Seismic implications of mantle wedge plumes: Physics of the Earth and Planetary Interiors v. 156, p. $59-74$.

Hawkesworth, C.J., Gallagher, K., Hergt, J.M. and McDermott F., 1993, Mantle and slab contributions in arc magmas: Annual Review Earth and Planetary Science, v. 21, p. 175-204.

Hawkesworth, C.J., Turner, S.P., Peate, D.W., McDermott, F. and van Calsteren, P., 1997, U-Th isotopes in arc magmas: implications for element transfer from the subducted crust: Science v. 276 , p. $551-555$. 
Hiess, J., Condon, D.J., McLean, N., and Noble, S.R., 2012, ${ }^{238} \mathrm{U} /{ }^{235} \mathrm{U}$ Systematics in Terrestrial Uranium-Bearing Minerals: Science v. 335, p. 1610-1614.

Hoffmann, D., Prytulak, J., Richards, D., Elliott, T., Coath, C.D., Smart, P.L., and Scholz, D., 2007, Procedures for accurate $U$ and Th isotope measurements by high precision MC-ICPMS: International Journal of Mass Spectrometry, v. 264, p. 97-109.

Kelemen, P.B., Rilling, J.L., Parmentier, E.M., Mehl, L., and Hacker, B.R., 2003, Thermal structure due to solid-state flow in the mantle wedge beneath arcs, in Eiler, J., and Hirschmann M., eds., Inside the Subduction Factory: American Geophysical union Monograph series v. 138, 293- 311.

Klimm, K., Blundy, J.D., and Green, T.H., 2008, Trace element partitioning and accessory phase saturation during $\mathrm{H}_{2} \mathrm{O}$-saturated melting of basalt with implications for subduction zone chemical fluxes: Journal of Petrology, v. 49, p. 523-553.

Marsella, M., Baldi, P., Coltelli, M., and Fabris, M., 2012, The morphological evolution of the Sciara del Fuoco since 1868: reconstructing the effusive activity at Stromboli volcano: Bulletin of Volcanology, v. 74, p. 231-248.

Ni, H.W., and Keppler, H., 2013, Carbon in silicate melts: in Hazen, R.M, Jones, A.P., and Baross, J.A., eds., Carbon in Earth: Review in Mineralogy and Geochemistry, v. 75, p. 251-287.

Nielsen, S.G. and Marshall, H.R., 2017. Geochemical evidence for mélange melting in global arcs: Science Advance v. 3, e1602402.

Peacock, S.M. 2003. Thermal structure and metamorphic evolution of subducting slab: in Eiler, J., and Hirschmann M., eds., Inside the Subduction Factory: American Geophysical union Monograph series v. 138, p. 293-311.

Peccerillo, A., 1985, Roman comagmatic province (Central Italy); evidence for subduction-related magma genesis: Geology v. 13, p. 103-106.

Peccerillo, A., 2001, Geochemical similarities between the Vesuvius, Phlegraean Fields and Stromboli Volcanoes: petrogenetic, geodynamic and volcanological implications: Mineralogy and Petrology, v. 73, p. 93-105.

Pichavant, M., Scaillet, M., Pommier, A., Iacono-Marziano, G., and Cioni, R., 2014, Nature and evolution of primitive Vesuvius magmas: an experimental study: Journal of Petrology, v. 55, p. 2281-2310.

Reubi, O., Bourdon, B., Dungan, M.A., Koornneef, J.M., Selles, D., Langmuir, C.H., and Aciego, S., 2011, Assimilation of the plutonic roots of the Andean arc controls variations in U-series disequilibria at Volcan Llaima, Chile: Earth and Planetary Science Letters, v. 303, p. 37-47.

Santacroce, R., Bertagnini, A., Civetta, L., Landi, P., and Sbrana, A., 1993, Eruptive dynamics and petrogenetic processes in a very shallow magma reservoir: the 1906 eruption of Vesuvius: Journal of Petrology, v. 34, p. 383-425.

Scandone, R., lannone, F. and Mastrolorenzo, G., 1986, Stima dei parametri dinamici dell'eruzione del 1944 del Vesuvio: Bollettino IGNV 1986, p. 487-512.

Tommasini, S., Heumann, A., Avanzinelli, R., and Francalanci, L., 2007, The fate of high angle dipping slabs in the subduction factory: an integrated trace element and radiogenic isotope $(\mathrm{U}, \mathrm{Th}, \mathrm{Sr}, \mathrm{Nd}, \mathrm{Pb})$ study of Stromboli volcano, Aeolian Arc, Italy: Journal of Petrology, v. 48, p. 2407-2430.

Treves, B., 1984, Orogenic belts as accretionary prisms: the example of the Northern Apennines: Ofioliti, v. 9, p. 577-618.

Thirlwall, M.F., 1991, Long-term reproducibility of multicollector $\mathrm{Sr}$ and $\mathrm{Nd}$ isotope ratio analysis: Chemical Geology, v. 94, p. 85-104.

Thomas, R.B., Hirschmann, M.M., Cheng, H., Reagan, M.K., and Edwards, R.L., 2002, $\left({ }^{231} \mathrm{~Pa} /{ }^{235} \mathrm{U}\right)-\left({ }^{230} \mathrm{Th} /{ }^{238} \mathrm{U}\right)$ of young mafic volcanic rocks from Nicaragua and Costa Rica and 
the influence of flux melting on U-series systematics of arc lavas: Geochimica et Cosmochimica Acta, v. 66, p. 4287-4309.

Weis, D., Kieffer, B., Maerschalk, C., Barling, J., de Jong, J., Williams,G.A., Hanano, D., Pretorius, W., Mattielli, N., Scoates, J.S., Goolaerts, A., Friedman, R.M., and Mahoney, J.B., 2006, High precision isotopic characterization of USGS reference materials by TIMS and MCICPMS: Geochemistry Geophysics Geosystems, v. 7, Q08006.

Zou, H., and Zindler, A., 2000, Theoretical studies of ${ }^{238} \mathrm{U}-{ }^{230} \mathrm{Th}-{ }^{226} \mathrm{Ra}$ and ${ }^{235} \mathrm{U}-{ }^{231} \mathrm{~Pa}$ disequilibria in young lavas produced by mantle melting: Geochimica et Cosmochimica Acta, v. 64, p. 1809-1817. 
Table DR 1. Eruption date, type, location, major and trace element composition of Vesuvius and Sediment samples

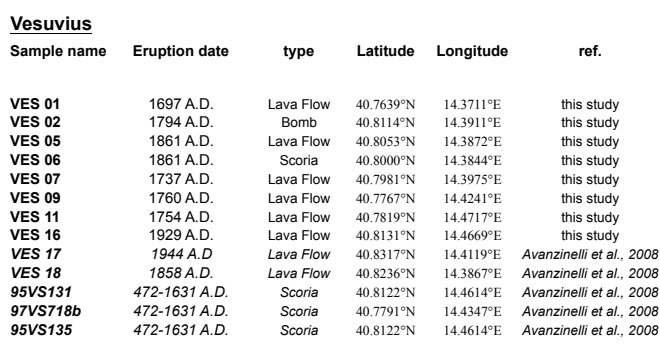

Sediments

$\begin{array}{ll}\text { SD } 11 & \text { Carbonate-poor marlstone } \\ \text { SD 48 } & \begin{array}{l}\text { Carbonate-rich marstone } \\ \text { Mesozoic Limestone }\end{array} \\ \text { ERN57 } & \end{array}$ \begin{tabular}{ccc} 
new data from Actlabs Laboratories, Ontario (Canaada) \\
\hline $\mathrm{Si}_{2} \quad \mathrm{TiO}_{2} \quad \mathrm{Al}_{2} \mathrm{O}_{3} \quad \mathrm{Fe}_{2} \mathrm{O}_{3}$
\end{tabular}

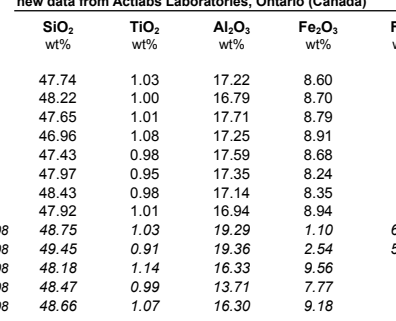

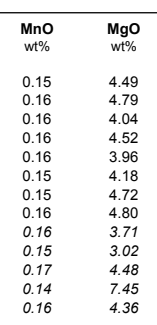

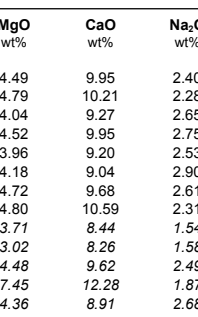

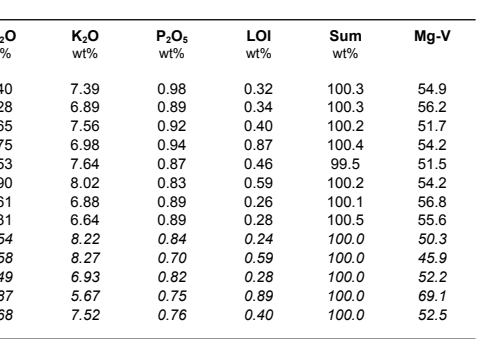

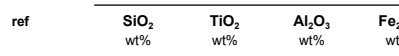

Mno

\section{cao}

$\mathrm{K}_{2} \mathrm{O}$
$\mathrm{w}+\%$

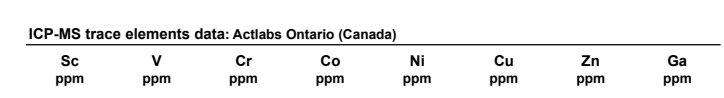

$\begin{array}{llllllll}17 & 265 & <20 & 27 & 30 & 100 & 60 & 18 \\ 22 & 261 & 50 & 27 & 30 & 110 & 70 & 18\end{array}$

\begin{tabular}{|c|c|c|c|c|c|c|c|}
\hline ICP-MS t & elemen & ta: new & erforme & ristol lis & Group & & \\
\hline $\begin{array}{c}\mathrm{sc} \\
\mathrm{ppm}\end{array}$ & $\underset{\mathrm{ppm}}{\mathrm{v}}$ & $\underset{\mathrm{ppm}}{\mathrm{Cr}}$ & $\begin{array}{c}\mathrm{Co} \\
\mathrm{ppm}\end{array}$ & 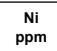 & $\begin{array}{c}\mathrm{Cu} \\
\mathrm{ppm}\end{array}$ & $\underset{\mathrm{ppm}}{\mathrm{zn}}$ & $\begin{array}{c}\mathrm{Ga} \\
\mathrm{ppm}\end{array}$ \\
\hline $\begin{array}{l}7.4 \\
5.4 \\
1.4\end{array}$ & 17 & $\vdots$ & $\begin{array}{l}6.14 \\
9.4 \\
1.9\end{array}$ & $\begin{array}{l}43.0 \\
48.0\end{array}$ & $\begin{array}{l}6.1 .5 \\
64.5 \\
3.10\end{array}$ & $\begin{array}{l}1420 \\
300 \\
14.7\end{array}$ & $\begin{array}{l}10.1 \\
9: 0\end{array}$ \\
\hline
\end{tabular}

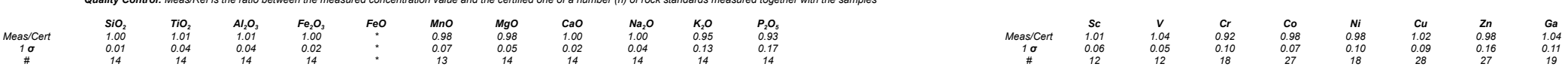

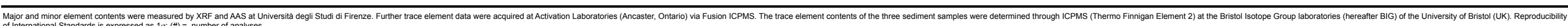
Table DRI. Continue

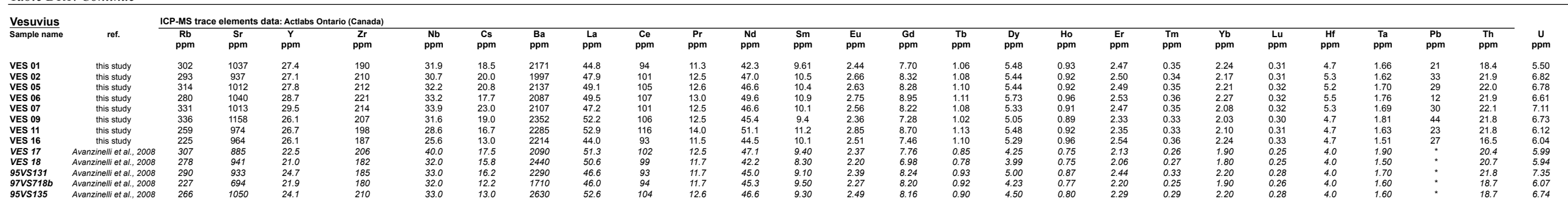

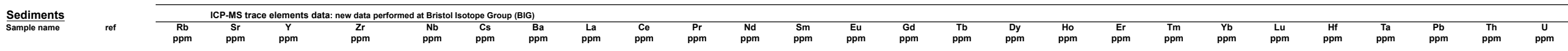

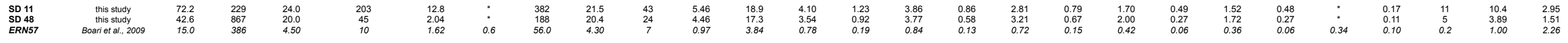

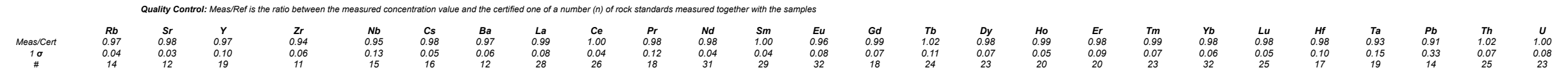




\section{Vesuvius}

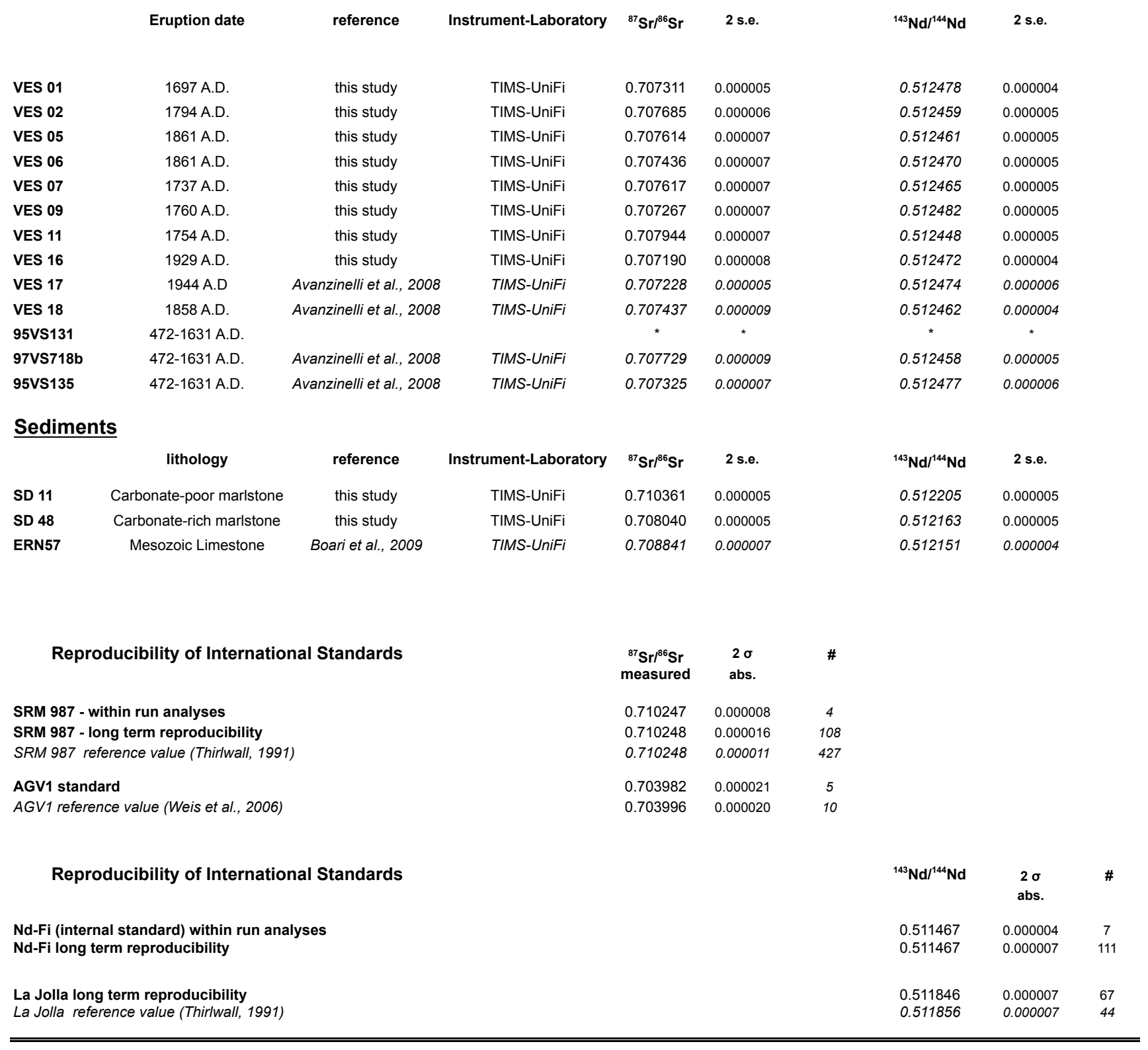

$\mathrm{Sr}$ and $\mathrm{Nd}$ isotopes were measured at the Radiogenic Isotopes Laboratory of the University of Firenze (Avanzinelli et al., 2005) with a Thermo Finnigan Triton Thermal Ionisation Mass Spectrometer (TIMS-UniFi) in multi-dynamic mode (Thirlwall, 1991). Internal errors on sample data ( \pm 2 s.e.) are fully propagated for all the corrections applied. Reproducibility of International Standards is expressed as $2 \sigma ;(\#)=$ number of analyses. Numbers in Italic are from Avanzinelli et al. (2008). 


\section{Vesuvius}

$\begin{array}{lrl} & \text { Eruption date } & \text { reference } \\ \text { VES 01 } & \text { 1697 A.D. } & \text { this study } \\ \text { VES 02 } & \text { 1794 A.D. } & \text { this study } \\ \text { VES 05 } & \text { 1861 A.D. } & \text { this study } \\ \text { VES 06 } & \text { 1861 A.D. } & \text { this study } \\ \text { VES 07 } & \text { 1737 A.D. } & \text { this study } \\ \text { VES 09 } & \text { 1760 A.D. } & \text { this study } \\ \text { VES 11 } & \text { 1754 A.D. } & \text { this study } \\ \text { VES 16 } & \text { 1929 A.D. } & \text { this study } \\ \text { VES 17 } & \text { 1944 A.D } & \text { this study } \\ \text { VES 18 } & \text { 1858 A.D. } & \text { this study } \\ \text { 95VS131 } & \text { 472-1631 A.D. } & \text { this study } \\ \text { 97VS718b } & \text { 472-1631 A.D. } & \text { this study } \\ \text { 95VS135 } & \text { 472-1631 A.D. } & \text { this study }\end{array}$

Instrument-Laboratory
MC-ICPMS - BIG
MC-ICPMS - BIG
MC-ICPMS - BIG
MC-ICPMS - BIG
MC-ICPMS - BIG
MC-ICPMS - BIG
MC-ICPMS - BIG
MC-ICPMS - BIG
MC-ICPMS - BIG
MC-ICPMS - BIG
MC-ICPMS - BIG
MC-ICPMS - BIG
MC-ICPMS - BIG

${ }^{206} \mathrm{~Pb} /{ }^{204} \mathrm{~Pb} \quad 2$ s.e.
initial

$19.079 \quad 0.008$

$18.982 \quad 0.008$

$19.010 \quad 0.008$

$19.026 \quad 0.008$

$19.009 \quad 0.008$

$19.043 \quad 0.008$

$18.961 \quad 0.007$

$19.115 \quad 0.008$

$19.021 \quad 0.008$

$19.080 \quad 0.008$

$19.007 \quad 0.008$

$18.912 \quad 0.007$

$19.078 \quad 0.008$
${ }^{207} \mathrm{~Pb} /{ }^{204} \mathrm{~Pb} \quad 2$ s.e.

15.692

15.694

15.684

15.700

15.688

15.685

15.689

15.691

15.696

15.695

15.698

15.685

15.696
0.005

0.005

0.005

0.005

0.005

0.005

0.005

0.005

0.005

0.005

0.005

0.005

0.005

$\begin{array}{cc}{ }^{208} \mathrm{~Pb}{ }^{204} \mathrm{~Pb} & 2 \text { s.e. } \\ \text { initial } & \\ 39.189 & 0.017 \\ 39.126 & 0.017 \\ 39.120 & 0.017 \\ 39.173 & 0.017 \\ 39.131 & 0.017 \\ 39.165 & 0.017 \\ 39.122 & 0.017 \\ 39.212 & 0.017 \\ 39.151 & 0.017 \\ 39.195 & 0.017 \\ 39.158 & 0.017 \\ 39.050 & 0.017 \\ 39.191 & 0.017\end{array}$

\section{Sediments}

\begin{tabular}{lll} 
& \multicolumn{1}{c}{ lithology } & reference \\
SD 11 & Carbonate-poor marlstone & this study \\
SD 48 & Carbonate-rich marlstone & this study
\end{tabular}

\begin{tabular}{|c|c|c|c|c|c|c|c|}
\hline \multicolumn{8}{|l|}{ Instrument-Laboratory } \\
\hline TIMS-UniFi & 18.851 & 0.013 & 15.679 & 0.015 & 38.910 & 0.056 & \\
\hline \multirow[t]{2}{*}{ TIMS-UniFi } & 18.864 & 0.013 & 15.675 & 0.003 & 38.908 & 0.056 & \\
\hline & $\begin{array}{l}{ }^{206} \mathrm{~Pb}^{1204} \mathrm{~Pb} \\
\text { measured }\end{array}$ & $\begin{array}{l}2 \sigma \\
\text { abs. }\end{array}$ & $\begin{array}{l}{ }^{207} \mathrm{~Pb}^{1204} \mathrm{~Pb} \\
\text { measured }\end{array}$ & $\begin{array}{l}2 \sigma \\
\text { abs. }\end{array}$ & $\begin{array}{l}{ }^{208} \mathrm{~Pb}^{1204} \mathrm{~Pb} \\
\text { measured }\end{array}$ & $\begin{array}{l}2 \sigma \\
\text { abs. }\end{array}$ & \# \\
\hline $\begin{array}{l}\text { MC-ICPMS - BIG } \\
\text { MC-ICPMS - double spike }\end{array}$ & $\begin{array}{r}36.755 \\
36.743\end{array}$ & 0.015 & $\begin{array}{r}17.166 \\
17.162\end{array}$ & 0.006 & $\begin{array}{r}36.754 \\
36.749\end{array}$ & 0.016 & 23 \\
\hline $\begin{array}{l}\text { MC-ICPMS - BIG } \\
\text { TIMS-UniFi } \\
\text { MC-ICPMS - TI correction } \\
\text { MC-ICPMS - double spike }\end{array}$ & $\begin{array}{l}18.753 \\
18.749 \\
18.753 \\
18.765\end{array}$ & $\begin{array}{l}0.015 \\
0.003 \\
0.002 \\
0.011\end{array}$ & $\begin{array}{l}15.629 \\
15.618 \\
15.625 \\
15.628\end{array}$ & $\begin{array}{l}0.009 \\
0.003 \\
0.004 \\
0.005\end{array}$ & $\begin{array}{l}38.744 \\
38.714 \\
38.724 \\
38.752\end{array}$ & $\begin{array}{l}0.035 \\
0.011 \\
0.041 \\
0.022\end{array}$ & $\begin{array}{c}8 \\
7 \\
11 \\
8\end{array}$ \\
\hline $\begin{array}{l}\text { MC-ICPMS - BIG } \\
\text { MC-ICPMS - TI correction } \\
\text { MC-ICPMS - double spike }\end{array}$ & $\begin{array}{l}18.641 \\
18.647 \\
18.649\end{array}$ & $\begin{array}{l}0.012 \\
0.024 \\
0.019\end{array}$ & $\begin{array}{l}15.532 \\
15.533 \\
15.540\end{array}$ & $\begin{array}{l}0.044 \\
0.009 \\
0.015\end{array}$ & $\begin{array}{l}38.242 \\
38.237 \\
38.249\end{array}$ & $\begin{array}{l}0.037 \\
0.018 \\
0.022\end{array}$ & $\begin{array}{c}10 \\
5 \\
5\end{array}$ \\
\hline $\begin{array}{l}\text { TIMS-UniFi } \\
\text { MC-ICPMS - TI correction } \\
\text { MC-ICPMS - double spike }\end{array}$ & $\begin{array}{l}18.941 \\
18.940 \\
18.942\end{array}$ & $\begin{array}{l}0.013 \\
0.006 \\
0.002\end{array}$ & $\begin{array}{l}15.654 \\
15.653 \\
15.658\end{array}$ & $\begin{array}{l}0.015 \\
0.004 \\
0.002\end{array}$ & $\begin{array}{r}38.566 \\
38.560 \\
38.569\end{array}$ & $\begin{array}{l}0.056 \\
0.010 \\
0.006\end{array}$ & $\begin{array}{c}11 \\
5 \\
12\end{array}$ \\
\hline
\end{tabular}

Reproducibility of International Standards

SRM 982 (BIG) - long term reproducibility

SRM 982 reference value (Baker et al., 2004)

\section{BCR 2 (BIG)}

BCR 2 (UniFi)

BCR 2 reference value (Weis et al., 2006)

$B C R 2$ reference value (Baker et al., 2004)

BHVO 2 (BIG)

BHVO 2 reference value (Weis et al., 2006)

BHVO 2 reference value (Baker et al., 2004)

AGV 1 (UniFi)

AGV 1 reference value (Weis et al., 2006)

AGV 1 reference value (Baker et al., 2004)

$\mathrm{Pb}$ isotope ratios of Vesuvius volcanic products were measured at BIG via Thermo-Finnigan Neptune MC-ICPMS. Instrumental mass fractionation was corrected by the average of the bracketing NIST SRM 981 run before and after the sample (Avanzinelli et al., 2014). Pb isotope ratios of the sediment samples were measured at the Radiogenic Isotopes Laboratory of the University of Firenze (i.e., UniFi) with a Thermo Finnigan Triton Thermal lonisation Mass Spectrometer (TIMS). Mass bias was corrected by replicate analyses of NIST SRM 981 as described in Avanzinelli et al., 2005. The reproducibility of the international rock standards is expressed as 2 sigma (2 $)$ ): \# = number of analyses. The internal errors ( \pm 2 s.e.) on the samples' ratio are calculated from the reproducibility of SRM982 (for BIG measurements) and AGV 1 standards (UniFi), respectively. Reference values (Baker et al., 2004; Weis et al., 2006) adopted different protocols for mass-bias corrections using ${ }^{205} \mathrm{TI}^{203} \mathrm{TI}$ (Weis et al., 2006) and a ${ }^{207} \mathrm{~Pb} /{ }^{205} \mathrm{~Pb}$ double-spike (Baker et al., 2004), respectively. 


\begin{tabular}{|c|c|c|}
\hline VES 01 & 1697 A.D. & this study \\
\hline rep & & this study \\
\hline & & this study \\
\hline VES 02 & 1794 A.D. & $\begin{array}{l}\text { this study } \\
\text { this study }\end{array}$ \\
\hline rep-2 2 & & this study \\
\hline VES 05 & 1861 A.D. & this study \\
\hline & & this study \\
\hline VES 06 & 1861 A.D. & this study \\
\hline VES 07 & 1737 A.D. & this study \\
\hline vep 09 & 1760 A.D. & $\begin{array}{l}\text { this study } \\
\text { this study }\end{array}$ \\
\hline rep & & this study \\
\hline VES 11 & 1754 A.D. & this study \\
\hline rep & & this study \\
\hline VES 16 & 1929 A.D. & $\begin{array}{l}\text { this study } \\
\text { this study }\end{array}$ \\
\hline VES 17 & 1944 A.D & this study \\
\hline rep & & this study \\
\hline $\begin{array}{l}\text { oublished } \\
\text { vacus }\end{array}$ & $1858 \mathrm{AD}$ & 1zinellif tall, 2008 \\
\hline Ves 18 & 1858 A.D. & $\begin{array}{l}\text { this study } \\
\text { this study }\end{array}$ \\
\hline rep-2 2 & & $\begin{array}{l}\text { mishs stouy } \\
\text { this study }\end{array}$ \\
\hline oublished & & Avanzinelli et al, 2008 \\
\hline 95VS131 & 472-1631 A.D. & this study \\
\hline $97 V S 718 b$ & 472-1631 A.D. & 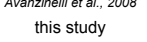 \\
\hline 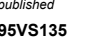 & 472-1631 A.D. & $\begin{array}{l}\text { inzininili talla, } 2008 \\
\text { this study }\end{array}$ \\
\hline oublished & & \\
\hline
\end{tabular}

Instrument-Laborato
MC-ICPMS - BIG
MC-ICPMS - BIG
MC-ICPMS - BIG
MC-ICPMS - BIG
MC-ICPMS - BIG
MC-ICPMS - BIG
MC-ICPMS - BIG
MC-ICPMS - BIG
MC-ICPMS - BIG
MC-ICPMS - BIG
MC-ICPMS - BIG
MC-ICPMS - BIG
MC-ICPMS - BIG

\begin{tabular}{|c|c|c|c|c|}
\hline$\underset{\mathrm{ppm}}{\mathrm{u}}$ & 2 s.e. & $\underset{\mathrm{ppm}}{\mathrm{Th}}$ & 2s.e. & $\left({ }^{(234} U / \int^{233} \mathrm{U}\right)$ \\
\hline 5.747 & 0.027 & 16.963 & 0.089 & 1.001 \\
\hline 5.744 & 0.028 & 17.029 & 0.081 & 1.003 \\
\hline 6.540 & 0.019 & 19.187 & 0.065 & 0.999 \\
\hline 7.070 & 0.030 & 19.818 & 0.089 & 1.009 \\
\hline 7.430 & 0.022 & 20.841 & 0.315 & 1.006 \\
\hline 7.101 & 0.024 & 19.731 & 0.074 & 0.999 \\
\hline 7.070 & 0.020 & 20.289 & 0.058 & 1.003 \\
\hline 7.067 & 0.026 & 20.170 & 0.077 & 0.996 \\
\hline 6.962 & 0.034 & 20.203 & 0.091 & 0.998 \\
\hline 6.332 & 0.019 & 18.487 & 0.056 & 1.003 \\
\hline 7.245 & 0.031 & 20.303 & 0.088 & 1.001 \\
\hline & 0.024 & 20.256 & 0.069 & 1.002 \\
\hline 7.250 & 0.032 & 20.519 & 0.095 & 1.002 \\
\hline 7.017 & 0.019 & 19.879 & 0.071 & 1.004 \\
\hline 6.498 & 0.029 & 20.454 & 0.088 & 0.994 \\
\hline 5.840 & 0.017 & 18.342 & 0.060 & 1.003 \\
\hline 4.659 & 0.022 & 15.489 & 0.068 & 1.003 \\
\hline 4.668 & 0.016 & 15.777 & 0.058 & 0.999 \\
\hline 6.293 & 0.025 & 19.096 & 0.077 & 1.001 \\
\hline 6.266 & 0.023 & 19.057 & 0.078 & 1.002 \\
\hline 6.30 & & 19.45 & & 1.001 \\
\hline 6.456 & 0.024 & 20.221 & 0.076 & 1.000 \\
\hline 6.412 & 0.026 & 20.048 & 0.089 & 1.001 \\
\hline 6.324 & 0.023 & 19.981 & 0.087 & 1.000 \\
\hline 6.340 & & 20.170 & & 1.001 \\
\hline 7.631 & 0.038 & 20.892 & 0.108 & 1.001 \\
\hline 7.600 & & 20.780 & & \\
\hline 6.214 & 0.031 & 17.524 & 0.084 & 1.003 \\
\hline $\begin{array}{l}6.230 \\
.200\end{array}$ & & 17.490 & & 1.002 \\
\hline 6.696 & 0.030 & 16.778 & 0.080 & 1.001 \\
\hline & & & & 0.999 \\
\hline
\end{tabular}

2 s.e. $\quad\left(^{238} \mathrm{U} /{ }^{232} \mathrm{~T}\right.$

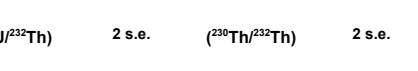

$\left.{ }^{230} \mathrm{Th} \mathbf{T}^{238} \mathrm{U}\right) \quad 2$ s.e.

$8^{238} U \quad 2$ s.e.

\title{
Sediments
}

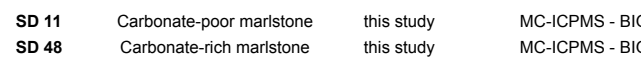

$\begin{array}{llll}\text { SD } 48 & \text { Carbonate-rich marlstone } & \text { this study } & \text { MC-ICPMS - BIC } \\ \text { ERN } 57 & \text { Mesozoic Limestone } & \text { this study } & \text { MC-ICPMS - BIC }\end{array}$

Reproducibility of International Standards

\section{BCR 2}

TML

JB 1

BHVO 2

0.002
0.002
0.002
0.002
0.002
0.001
0.002
0.002
0.002
0.002
0.002
0.002
0.001
0.002
0.002
0.002
0.002
0.002
0.002
0.002
0.003
0.002
0.002
0.002
0.003
0.002
0.004
0.002
0.004
0.002
0.003

\begin{tabular}{ll}
1.028 & 0.008 \\
1.024 & 0.008 \\
1.034 & 0.005 \\
1.082 & 0.008 \\
1.082 & 0.018 \\
1.092 & 0.006 \\
1.057 & 0.006 \\
1.063 & 0.007 \\
1.046 & 0.007 \\
1.039 & 0.005 \\
1.083 & 0.005 \\
1.075 & 0.006 \\
1.072 & 0.008 \\
1.071 & 0.005 \\
0.964 & 0.007 \\
0.966 & 0.005 \\
0.913 & 0.004 \\
0.998 & 0.005 \\
1.000 & 0.007 \\
0.998 & 0.007 \\
0.983 & 0.005 \\
0.969 & 0.006 \\
0.970 & 0.007 \\
0.960 & 0.006 \\
0.953 & 0.004 \\
1.108 & 0.008 \\
1.112 & 0.006 \\
1.076 & 0.008 \\
1.083 & 0.005 \\
1.211 & 0.008 \\
1.215 & 0.006 \\
\hline &
\end{tabular}

\begin{tabular}{ll}
0.897 & 0.002 \\
0.886 & 0.003 \\
0.890 & 0.002 \\
0.871 & 0.003 \\
0.877 & 0.002 \\
0.868 & 0.003 \\
0.873 & 0.004 \\
0.871 & 0.003 \\
0.886 & 0.002 \\
0.865 & 0.002 \\
0.874 & 0.000 \\
0.869 & 0.003 \\
0.921 & 0.002 \\
0.899 & 0.002 \\
0.850 & 0.003 \\
0.852 & 0.002 \\
0.881 & 0.002 \\
0.865 & 0.002 \\
0.874 & 0.003 \\
0.874 & 0.004 \\
0.868 & 0.005 \\
0.891 & 0.003 \\
0.886 & 0.000 \\
0.880 & 0.003 \\
0.878 & 0.005 \\
0.904 & 0.002 \\
0.896 & 0.005 \\
0.881 & 0.003 \\
0.882 & 0.000 \\
0.890 & 0.002 \\
0.887 & 0.005 \\
\hline
\end{tabular}

\begin{tabular}{ll}
0.872 & 0.003 \\
0.866 & 0.003 \\
0.861 & 0.003 \\
0.805 & 0.003 \\
0.811 & 0.014 \\
0.795 & 0.003 \\
0.825 & 0.004 \\
0.819 & 0.004 \\
0.847 & 0.003 \\
0.851 & 0.003 \\
0.807 & 0.000 \\
0.809 & 0.003 \\
0.859 & 0.003 \\
0.839 & 0.003 \\
0.882 & 0.004 \\
0.882 & 0.003 \\
0.965 & 0.004 \\
0.963 & 0.004 \\
0.874 & 0.004 \\
0.876 & 0.005 \\
0.884 & 0.004 \\
0.920 & 0.004 \\
0.913 & 0.004 \\
0.916 & 0.004 \\
0.921 & 0.003 \\
0.816 & 0.003 \\
0.006 & 0.003 \\
0.819 & 0.003 \\
0.815 & 0.003 \\
0.735 & 0.002 \\
0.728 & 0.003 \\
\hline
\end{tabular}

$\begin{array}{lll}\text { VES } 01 & -0.30 & 0.02 \\ \text { rep. } & -0.22 & 0.06\end{array}$

0.014

0.003

0.003
0.000
0.003

VES $07 \quad-0.27 \quad 0.03$

VES $16 \quad-0.26 \quad 0.04$

$\begin{array}{lll}\text { VES } 17 & -0.29 & 0.02 \\ \text { rep. } & -0.31 & 0.05\end{array}$

$\begin{array}{lll}\text { VES } 18 & -0.12 & 0.04\end{array}$

$\begin{array}{lll}97 \mathrm{~V} 718 \mathrm{~b} & -0.19 & 0.04\end{array}$

$\begin{array}{lll}95 \mathrm{~V} 135 & -0.24 & 0.04\end{array}$

\begin{tabular}{lll} 
& $\boldsymbol{\delta}^{238} \mathbf{U}$ & $\mathbf{2}$ s.e. \\
SD 11 & -0.08 & 0.02 \\
SD 48 & 0.19 & 0.06 \\
ERN 57 & -0.67 & 0.04 \\
rep & -0.68 & 0.03 \\
\hline
\end{tabular}

\begin{tabular}{lll}
-0.68 & 0.04 \\
rep & -0.67 & 0 \\
\hline
\end{tabular}

\begin{tabular}{|c|c|c|c|c|c|c|c|c|c|c|c|}
\hline u & $2 \sigma(\#)$ & Th & $2 \sigma(\#)$ & $\left({ }^{(23} \mathrm{U} / \mathrm{I}^{238} \mathrm{U}\right)$ & $2 \sigma(\#)$ & $\left({ }^{238} \mathrm{U}{ }^{232} \mathrm{Th}\right)$ & $2 \sigma(\#)$ & $\left.{ }^{(230} \mathrm{Th}^{2}{ }^{232} \mathrm{Th}\right)$ & $2 \sigma(\#)$ & $\left({ }^{230} \mathrm{~T} /{ }^{238} \mathrm{U}_{i}\right.$ & $2 \sigma(\#)$ \\
\hline 1.693 & 0.027 (17) & 5.885 & $0.105(17)$ & 1.002 & 0.006 (17) & 0.873 & $0.006(17)$ & 0.877 & $0.006(17)$ & 1.005 & 0.006 (17) \\
\hline 10.51 & $0.20(23)$ & 29.78 & $0.77(23)$ & 1.000 & $0.004(23)$ & 1.071 & $0.012(23)$ & 1.072 & $0.013(23)$ & 1.001 & 0.009 (23) \\
\hline
\end{tabular}

\begin{tabular}{lcc} 
& $8^{238} \mathbf{U}$ & $2 \sigma(\#)$ \\
BCR 2 & -0.280 & $0.028(2)$ \\
& & \\
CZ1 & -0.045 & $0.037(8)$ \\
JB 2 & -0.313 & $0.076(3)$ \\
BHVO 2 & -0.313 & $0.093(4)$ \\
\hline
\end{tabular}

${ }^{238} \mathrm{U}-{ }^{230} \mathrm{Th}$ disequilibria were measured by isotoptope dilution using established techniques (Hoffmann et al., 2007; Avanzinelli et al., 2014) at BIG via MC-ICPMS by bracketing each sample between two standards, U112a for U measurements and an internal Th-standard for Th analyses. The possible influence of weathering or seawater alteration was checked by measuring $\left({ }^{234} \mathrm{U} /{ }^{238} \mathrm{U}\right)$ of the samples, all of which resulted within error of secular equilibrium values. Th and $U$ contents are ppm. Parentheses denote isotope ratios are expressed as activity.

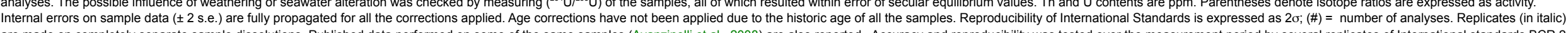
are made on completely separate sample dissolutions. Published data pert
and TML, all yielding values indistinguishable from secular equilibrium.

${ }^{238} \mathrm{U} /{ }^{235} \mathrm{U}$ was measured via MC-ICPMS at BIG according to the procedure described in Andersen et al. $(2014,2015)$ using the IRMM-3636 ${ }^{23} \mathrm{U}-{ }^{236} \mathrm{U}$ double spike. A two-step sample purification procedure by TRU Resin chemistry allowed full U recovery (>85\%) and total chemistry blanks of $25 \mathrm{pg}$ for all samples (negligible comparing with sample sizes). Measurements of unknown samples were bracketed and normalised to the CRM 145 standard that had been previously spiked. The mass bias corrected ${ }^{238} \mathrm{U} / 25 \mathrm{U}$ ratios were reported to $\delta$-notation using the ${ }^{238} \mathrm{U} /{ }^{235} \mathrm{U}=137.829( \pm 0.022) \mathrm{CRM} 145$ value (Hiess et al., 2012). The $\delta^{238} \mathrm{U}$ was then normalised to the bracketed standard values measured along with the samples. 
Table DR5. Trace element and isotope composition of the end-members used to model the mantle source of the Vesuvius magmas

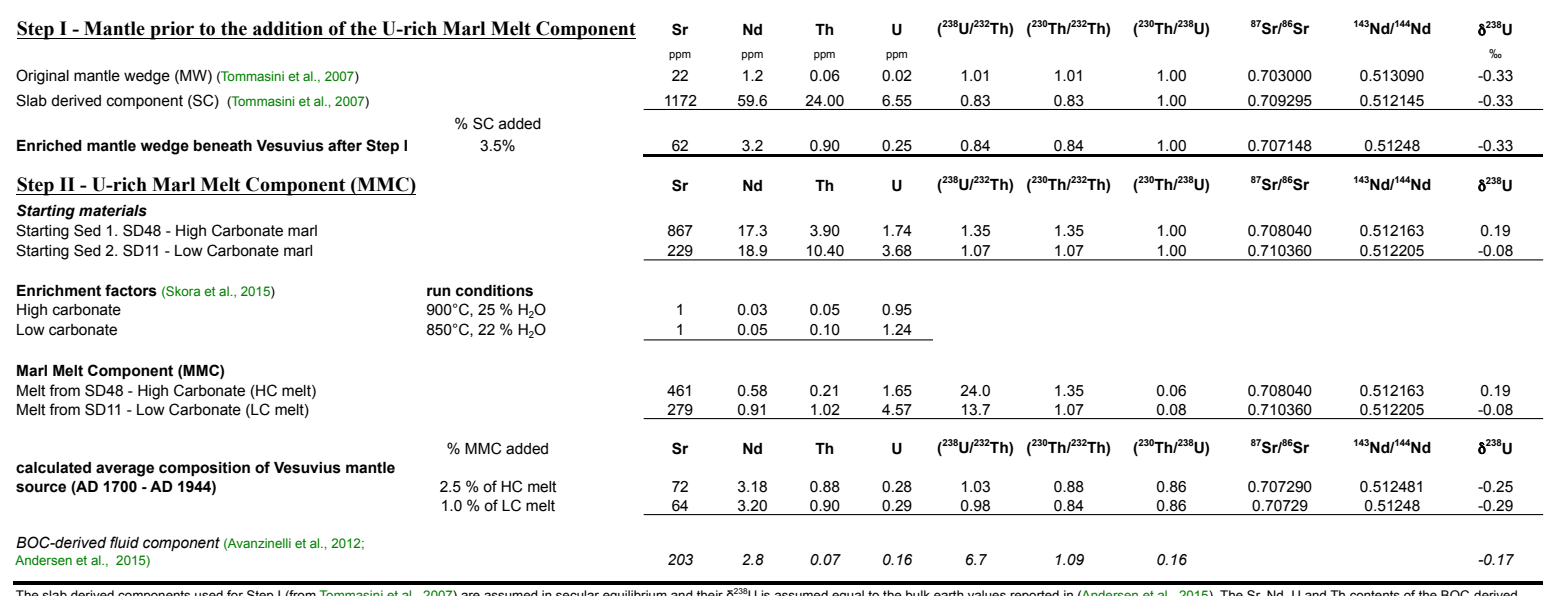

The slab derived components used for Step I (from Tommasini et al,, 2007) are assumed in secular equilibrium and their ${ }^{228} \mathrm{U}$ is assumed equal to the bulk earth values reported in (Andersen et all, 2015). The Sr, Nd, U and Th contents of the BOC-derived fluids (used in Figs. 2 and DR2) are from (Avanzinellie tal,, 2012) and its $\delta^{238} \mathrm{U}$ is the average BOC value reported in Andersen et al., 2015). The paper of Skora et all, 2015 does not provide partition coefficients, but rather enrichment factors (i.e., the
composition of the melt generated ratioed to that of the stating material), hence utilising such enrichment factors we implicitly assume similar degree of melting. 
Table DR6. Estimates of $\mathrm{CO}_{2}$ content in the Marl Melt Component (MMC)

\begin{tabular}{|c|c|c|c|c|}
\hline & $\begin{array}{c}\text { 144-16 HC } \\
\text { carbonate-rich marl } \\
\text { Skora et al., } 2015\end{array}$ & $\begin{array}{c}\text { SD } 48 \\
\text { carbonate-rich marl } \\
\text { this study }\end{array}$ & $\begin{array}{c}\text { 144-38 LC } \\
\text { carbonate-poor marl } \\
\text { Skora et al., } 2015\end{array}$ & $\begin{array}{c}\text { SD } 11 \\
\text { carbonate-poor marl } \\
\text { this study }\end{array}$ \\
\hline Initial $\mathrm{CO}_{2}(\mathrm{wt} \%)$ & $16.2 \%$ & $18.2 \%$ & $6.1 \%$ & $7.0 \%$ \\
\hline$\%$ residual $\mathrm{CaCO}_{3}$ & $25.0 \%$ & $25.0 \%$ & $2.0 \%$ & $2.0 \%$ \\
\hline $\mathrm{CO}_{2}$ in residual $\mathrm{CaCO}_{3}\left(\mathrm{wt} \%{ }^{\mathrm{a}}\right)$ & $11.0 \%$ & $11.0 \%$ & $0.9 \%$ & $0.9 \%$ \\
\hline $\mathrm{CO}_{2}$ lost with melt $\left(\mathrm{wt} \%^{\mathrm{a}}\right)$ & $5.2 \%$ & $7.2 \%$ & $5.2 \%$ & $6.1 \%$ \\
\hline$\%$ sed melt & $58.0 \%$ & $58.0 \%$ & $66.0 \%$ & $66.0 \%$ \\
\hline $\mathrm{CO}_{2}$ carried with sed. melt (wt\%) & $9.0 \%$ & $12.4 \%$ & $7.9 \%$ & $9.3 \%$ \\
\hline
\end{tabular}

\footnotetext{
The amount of $\mathrm{CO}_{2}$ retained in carbonate is calculated by stoichiometrically allotting it into the $\mathrm{CaCO}_{3}$ formula. Numbers in Italic are estimated assuming similar $\mathrm{CO}_{2} / \mathrm{LOI}$ and phase proportions of the $\mathrm{HC}$ and LC sediments reported in Skora et al. (2015). ${ }^{a}$ : The \% values are referred to the bulk initial marl. The remaining $\mathrm{CO}_{2}$ has been redistributed into melt in order to provide an estimate of the $\mathrm{CO}_{2}$ contents carried along wih it. See the Data Repository for further explanations
} 
Table DR7. Parameters used for $\mathrm{CO}_{2}$ flux calculations

\section{Period of activity}

\section{Variable parameters}

$\%$ of marl melt added: \%MMC

mean [U] of Vesuvius mantle source : $[U]_{M S}$

Vesuvius Output/Supply Rate (volume/year)

$[U]_{E R}$

$\left[\mathrm{CO}_{2}\right]_{M M C}$

\section{Calculated masses and fluxes}

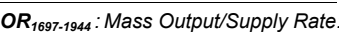

$f U_{E R}=f U_{M S}:$ Uranium mass flux:

$f U_{E R}=f U_{M s}:$ Uranium mass flux:
$f_{M S}:$ Mass rate of mantle source undergoing

meltina:

$\boldsymbol{f}_{\text {MMC }}$ : Mass Flux of MMC:

AD 1697- AD 1944

example $\mathrm{HC}$-marl addition 